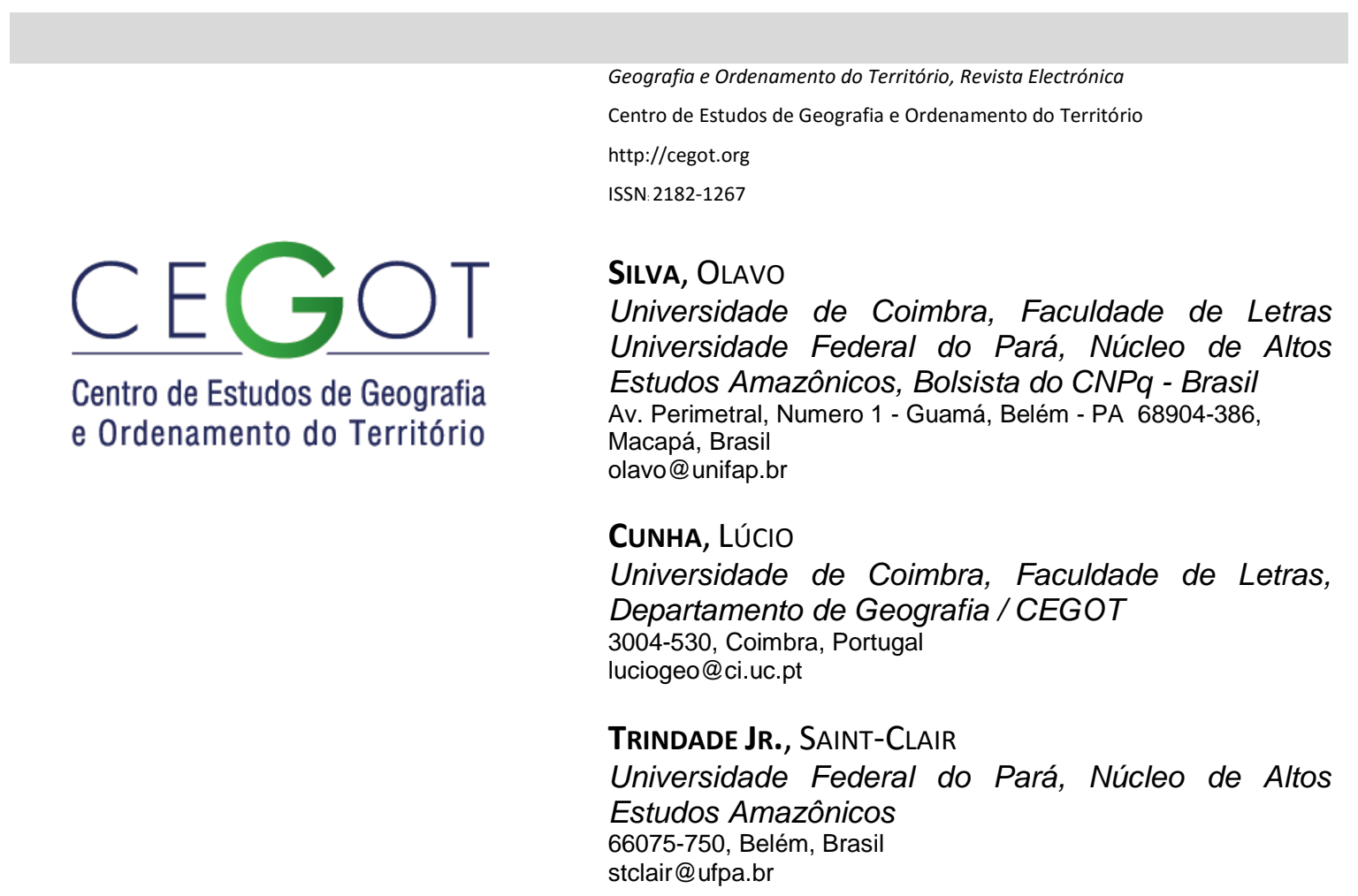

\title{
Uso do solo e infraestrutura viária na relação com as dinâmicas produtivas em assentamentos agroextrativistas no Amapá
}

\author{
Land use and road infrastructure in relation to the productive dynamics in \\ agro-extractive settlements in Amapá
}

Referência: Silva, Olavo et al. (2016). Uso do solo e infraestrutura viária na relação com as dinâmicas produtivas em assentamentos agroextrativistas no Amapá. Revista de Geografia e Ordenamento do Território (GOT), n.o 9 (junho). Centro de Estudos de Geografia e Ordenamento do Território, p. 281-305, dx.doi.org/10.17127/got/2016.9.013

\section{RESUMO}

Este trabalho analisa aspectos de uso do solo e as condições gerais da rede viária terrestre na relação com as dinámicas produtivas nos Projetos de Assentamentos Agroextrativistas do Cedro, Bom Jesus dos Fernandes e Governador Janary no município de Tartarugalzinho, centro/leste do Amapá. A pesquisa utilizou-se de dados documentais de órgãos públicos como INCRA, IBAMA e IMAP, levantamentos de dados e informações em campo e processamento de imagens SRTM e arquivos vetoriais em SIG. Identificou-se e caracterizouse o uso do solo, altimetria do relevo, hidrografia, e as condições da infraestrutura viária terrestre. Embora existam possibilidades de mudanças benéficas, atualmente, as atividades produtivas praticadas nos assentamentos resultam de modelos implantados na Amazônia Brasileira de forma tradicional, pouco sustentáveis e ineficazes para prover melhoria nas infraestruturas existentes e na qualidade de vida nos assentamentos. 
Palavras-chave: Amazônia Brasileira. Assentamentos rurais. Estradas. Extrativismo. Exclusão social

\section{ABSTRACT}

This paper analyzes aspects of land use and the general conditions of the land road network in relation to the productive dynamics in Agroextractive Settlements Project of Cedro, Bom Jesus dos Fernandes and Governador Janary in the municipality of Tartarugalzinho, center / east of Amapá. The research used documentary data from government agencies such as INCRA, IBAMA and IMAP, data surveys and information in the field and processing of SRTM images and vector files in GIS. Was identified and characterized land use, relief altimetry, hydrography, and the conditions of the road infrastructure. Although there are possibilities for beneficial changes, nowadays, the productive activities practiced in the settlements result from traditional models implemented in the Brazilian Amazon, unsustainable and ineffective to provide improvements in existing infrastructure and quality of life in the settlements.

Keywords: Brazilian Amazon. Rural settlements. Roads. Extraction. Social exclusion

\section{Introdução}

No que concerne ao meio físico e a estrutura da paisagem, as lições do passado e do presente tem apontado que a política agrária adotada pelo Estado Brasileiro para Amazônia deve conter alguns elementos que a diferenciem daquela adotada para outras regiões do país. Por sua extensão e pela diversidade dos seus ecossistemas, a Amazônia necessita de instrumentos de controle ambiental específicos, que permitam o uso do solo em consonância com mecanismos que maximizem a sustentabilidade social e ambiental.

Como os demais estados da Amazônia Brasileira, o Amapá em função da vasta disponibilidade de recursos naturais, possui uma vocação natural para atividades produtivas de base rural. Com aproximadamente $71 \%$ de seus $143.453,7 \mathrm{~km}^{2}$ constituídos por áreas protegidas legalmente, os assentamentos rurais ganham no estado importância para o aproveitamento dos recursos naturais e para a implantação de atividades produtivas extrativas rurais. Nesse contexto, a extração florestal madeireira e também a extração mineralógica em escala industrial constituem-se como duas das principais atividades produtivas do estado. 
Por força de mecanismos legais recentes abriu-se a possibilidade para que as atividades extrativistas, madeireira e mineral possam também ser desenvolvidas em assentamentos rurais, apesar de pouco se identificarem com as atividades fim prioritárias para serem desenvolvidas nessas áreas. Contudo, é fato que ambas carregam a idéia de um significativo incremento de renda para os trabalhadores nos assentamentos rurais. Ainda assim, pesa negativamente à implantação da extração industrial madeireira e mineralógica o fato de que tradicionalmente na Amazônia Brasileira, ambas são realizadas quase sempre em caráter economicamente e socialmente pouco sustentável.

Sobre a sustentabildade econômica de uma atividade produtiva, Castro (1998) lembra que para mantê-la, o processo produtivo e a eficácia económica devem obrigatoriamente "respeitar os limites e restrições do meio ambiente". De igual maneira, uma atividade produtiva para ser sustentável socialmente, deve ser desenvolvida de forma a atender "as necessidades básicas da população em termos materiais, de serviços e convivência". No Amapá, só recentemente algumas medidas como a exigência dos planos de manejo, tem procurado mudar o quadro de degradação ambiental e social que tradicionalmente acompanha as atividades da indústria madeireira e mineralógica.

O debate sobre a necessidade de repensar o velho modelo produtivo na Amazônia, baseado na extração de madeira nativa e minério, surgiu em meados da década de 90 do século XX. Naquele momento o Estado Brasileiro procurava de todas as formas, cumprir os acordos e compromissos assumidos após a ECO 92 - Convenção sobre mudanças climáticas e Meio Ambiente, ocorrida na cidade do Rio de Janeiro em 1992 (CORDANI et.al. 1997). Como parte das políticas federais para mudança dos modelos de apropriação madeireira, foram criados e implantados nos estados Amazônicos os Projetos de Assentamentos Agro-extrativistas (PAE).

Um dos objetivos da criação e implantação dos PAE era conciliar a política de reforma agrária com modelos de apropriação que conjugassem o aproveitamento das terras cedidas aos assentados com a conservação ambiental. O uso da floresta pressupunha na lógica da criação dos PAE, a conservação das condições gerais de reprodução da floresta e do meio físico que a envolve como um todo sistêmico. Uma das medidas tomadas com objetivo de regular a utilização das florestas em terras públicas e, portanto, também nos PAE, foi a instituição da Autorização Prévia à Análise Técnica de Plano de Manejo Florestal Sustentável (APAT) através da Instrução Normativa № 4, de 11 de dezembro de 2006 do Ministério do Meio Ambiente (BRASIL,2006) . 
Com as APATs os Projetos de Assentamentos Agro-extrativistas puderam ser contemplados com a possibilidade de legalização e ordenamento da extração madeireira e de outros Produtos Florestais não Madeireiros (PFNM), dentre estes, a castanha da Amazônia e o açaí. Do ponto de vista legal, o Plano de Manejo Florestal Sustentável (PMFS) abriu também possibilidades para o desenvolvimento de outras atividades produtivas além daquelas relacionadas aos produtos florestais propriamente. Para Soares $(2008$, p.146) a falta de planejamento adequado dos PAE na Amazônia acabou por priorizar atividades extrativistas pouco sustentáveis, a resultar na maioria dos casos em degradação socioambiental.

A tradicional modalidade de assentamentos rurais no Brasil é voltada principalmente para atividades produtivas ligadas à agropecuária com a finalidade de produção de excedentes e pressupõe a apropriação e uso coletivo do solo rural. Essa modalidade de assentamento rural nunca emplacou completamente na Amazônia, pois nessa região do país, a fixação do homem ao meio rural tende a conjugar uma diversidade de fatores. Dentre os mais relevantes destaca-se a vocação quase natural para o desenvolvimento de atividades extrativas ou de coleta, seja pelo modo de vida, herdado dos antepassados, seja pela abundância e conhecimento intrínseco dos recursos florestais. Outro fator que deve ser levado em consideração no processo de fixação das populações rurais na Amazônia é a habitual dispersão no território, esse fator se configura como uma das bases do processo de territorialização das populações rurais na imensidão Amazônica.

No Amapá, é fato que desde os primórdios da apropriação portuguesa, a relação do ribeirinho ou do homem do interior com os solos e as florestas, sempre conjugou a atividade agropecuária de subsistência com o extrativismo, notadamente aquele voltadado para a coleta ou extração de PFNM. Esse tipo de atividade, com fortes alicerces no sul do estado, acabou por levar à implantação de um processo produtivo com base em Sistemas Agroflorestais (SAF). Esse modelo produtivo foi replicado em grande parte dos assentamentos rurais do estado.

Os SAF, de acordo com Moraes (2011),são sistemas produtivos agropecuários cuja resença de um componente arbóreo ou lenhoso tem influência primordial sobre a estrutura e a função do sistema. Esse sistema produtivo, por priorizar uma relação mais harmoniosa entre o uso produtivo do solo rural e a conservação das condições naturais da biota, tornou-se carro chefe da política de desenvolvimento produtivo nos assentamentos rurais na Amazônia. Os SAF ainda que constituam uma forma de uso do solo mais adequada aos objetivos dos assentamentos rurais, com a implantaçãos das APATs e a forte vocação 
natural do estado para atividades industriais de base extrativa mineral e florestal, passaram a concorrer naquilo que parece ser uma mudança no processo produtivo no interior de alguns PAE.

A princípio não há qualquer contradição entre a mineração industrial e a atividade fim dos PAE. Entretanto, a falta de diálogo entre os agentes envolvidos nesse processo de apropriação pode significar o aceite de velhas práticas de exploração com máxima retirada dos recursos minerais e reduzida agregação de valor social e económico, como bem salienta Carvalho (2008, p.46). No caso do Amapá, essa prática teve sua expressão mais significativa com a instalação do polo mineralógico de Serra do Navio. A exploração do minério de manganês pela Indústria e Comercio de Minérios S/A (ICOMI), iniciado em fins da década de 50 e encerrado no início da década de 90 do século XX, tornou-se um clássico exemplo dos ativos sociais e económicos, quase sempre negativos em longo prazo, que empreendimentos mineralógicos deixariam posteriormente na Amazônia Brasileira e mais especificamente no estado do Amapá.

\subsection{Problemática, objetivos e área de estudo}

Quais os usos preponderantes do solo rural nos assentamentos agroextrativistas do Cedro, Bom Jesus dos Fernandes e Governador Janary no Amapá e que relação existe entre esses usos, as condições do sistema viário terrestre e o modo de vida dos assentados? Esse é um questionamento central para compreender o atual contexto social e económico em que se encontram essas áreas de apropriação coletiva. O objetivo do trabalho foi identificar os usos preponderantes do solo, as condições do sistema viário e sua relação com as dinámicas produtivas e condições atuais de vida nos assentamentos. A partir da análise das relações sociais e económicas que envolvem as atividades produtivas nos SAF e no extrativismo madeireiro e mineral e sua atuação na ampliação e manutenção do sistema viário interno, procurou-se avaliar esse contexto.

É fato que o sistema de rodovias não pavimentadas, responsável pela mobilidade e interligação nos assentamentos com o mundo exterior, espelha em boa medida o grau de desenvolvimento social e económico alcançado nessas áreas desde sua criação. Aparentemente há uma letargia geral que se revela diante do quadro de precariedade da estrutura viária. Esse quadro por sua vez demonstra uma condição limitante de grande peso no processo de desenvolvimento socioeconómico dos PAE e na melhoria da qualidade de vida dos assentados. 
Os assentamentos, Bom Jesus dos Fernandes, Cedro e Governador Janary constituem o conjunto de assentamentos adjacentes com maior área na região centro/leste do Amapá. A área total somada dos três assentamentos é de $1035,84 \mathrm{~km}^{2}$, sendo $592,22 \mathrm{~km}^{2}$ do assentamento Cedro, 330,67 km² do assentamento Bom Jesus dos Fernandes e 112,95 km² do assentamento Governador Janary. Os três assentamentos ocupam 15,36 \% da área do município de Tartarugalzinho que é de $6742 \mathrm{~km}^{2}$. Esse conjunto de assentamentos está situado no oeste do município de Tartarugalzinho mais ou menos no centro/leste do estado, sendo limitados a leste pela BR 156 e pelas terras da SPG Mineração e a norte, oeste e sul pela Floresta Estadual de Produção-FLOTA (Figura 1).

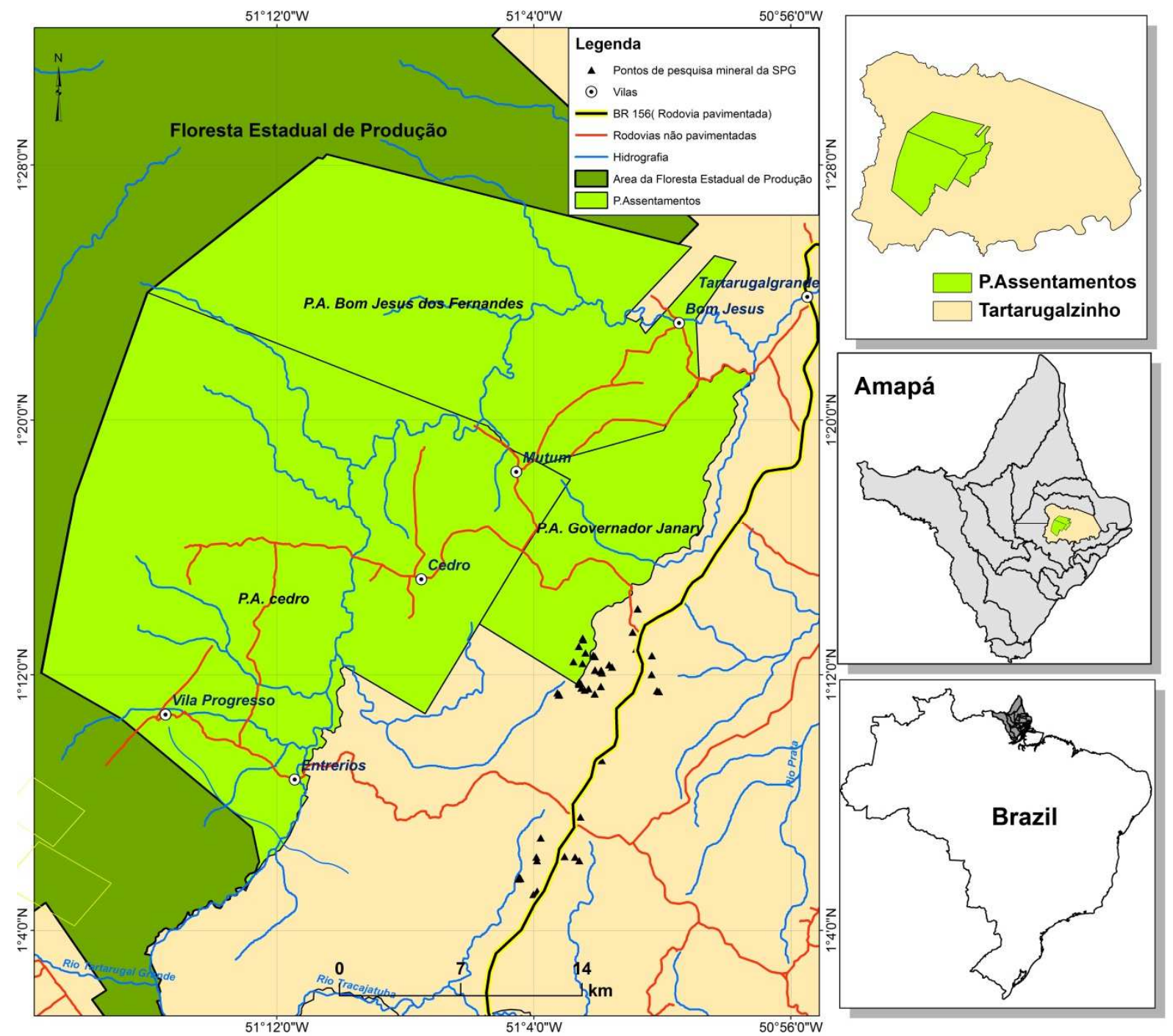

Figura 1: Localização e rede viária terrestre dos PAE Bom Jesus dos Fernandes, Cedro e Governador Janary. 


\section{Metodologia}

Para Santos (1999), as estruturas espacializadas no território definem a configuração territorial e esta expressa em boa medida as dinámicas sociais e económicas que nele se processam. A organização do espaço e as dinámicas que se imprimem na paisagem são produto e processo das forças sociais e sociais naturais atuantes ao longo do tempo. Portanto, a condição estrutural revela em boa medida a dinámica social impressa ao longo do tempo histórico.

Os sistemas produtivos se configuram como "sistemas de ações" que são ao mesmo tempo causa e efeito da estrutura na paisagem, que se configura como "sistema de objetos" sociais e sociais-naturais. As condições desses sistemas indissociáveis expressa, portanto a dinámica na paisagem sob a perspectiva da atuação dos grupos sociais como delineadores da eficácia ou não das dinámicas no processo desenvolvimento regional pretérito e presente.

Sob a pespectiva da análise das estruturas no tempo histórico, a pesquisa incluiu visitas técnicas para levantamentos documentais de dados e informações no Instituto Nacional de Colonização e Reforma Agrária (INCRA), no Instituto Brasileiro do Meio Ambiente e Recursos Naturais Renováveis (IBAMA) e Instituto do Meio Ambiente e Ordenamento Territorial do Amapá (IMAP). Também foram realizados trabalhos de campo nos assentamentos para registro de dados e informações relativas a estradas, trilhas, pontes, meio físico em geral e realidade socioeconómica. Para percorrer as estradas dos assentamentos foram realizadas previamente algumas entrevistas informais com moradores das vilas do Cedro e Entrerios cujo objetivo foi obter informações sobre as condições gerais de trafegabilidade das vias terrestres nos assentamentos.

Após avaliação das informações registradas durante as entrevistas foi confeccionado o mapa viário prévio, para o deslocamento em campo, também inserido no aparelho receptor GPS. Dadas as condições de manutenção informadas previamente nas entrevistas, optou-se por deslocamentos em veículo tipo passeio de pequenas dimensões com a finalidade de possibilitar a passagem nos possíveis trechos críticos de estradas e pontes deterioradas a serem eventualmente percorridas.

Durante os deslocamentos pelas estradas realizaram-se registros de pontos, polígonos e feições lineares utilizando-se aparelho receptor GPS modelo ETREX 20, da marca GARMIM. 
As medidas de avaliação das estradas, trilhas e pontes foram realizadas utilizando-se trena de 30 metros e cones sinalizadores além da percepção empírica e registro em caderneta de campo e com máquina digital, das condições físicas de manutenção das vias.

Para a classificação do sistema viário dos assentamentos utiizou-se a metodologia estabelecida no Projeto Geométrico de Rodovias Rurais (BRASIL, 1999) e no Manual Básico de Estradas e Rodovias Vicinais (São Paulo, 2012). A classificação estabelecida nos dois documentos tem como principal critério a funcionaliadade das vias (Figura 2), mas diferem quanto a critérios como extensão e caracterísicas geométricas e de fluxos.

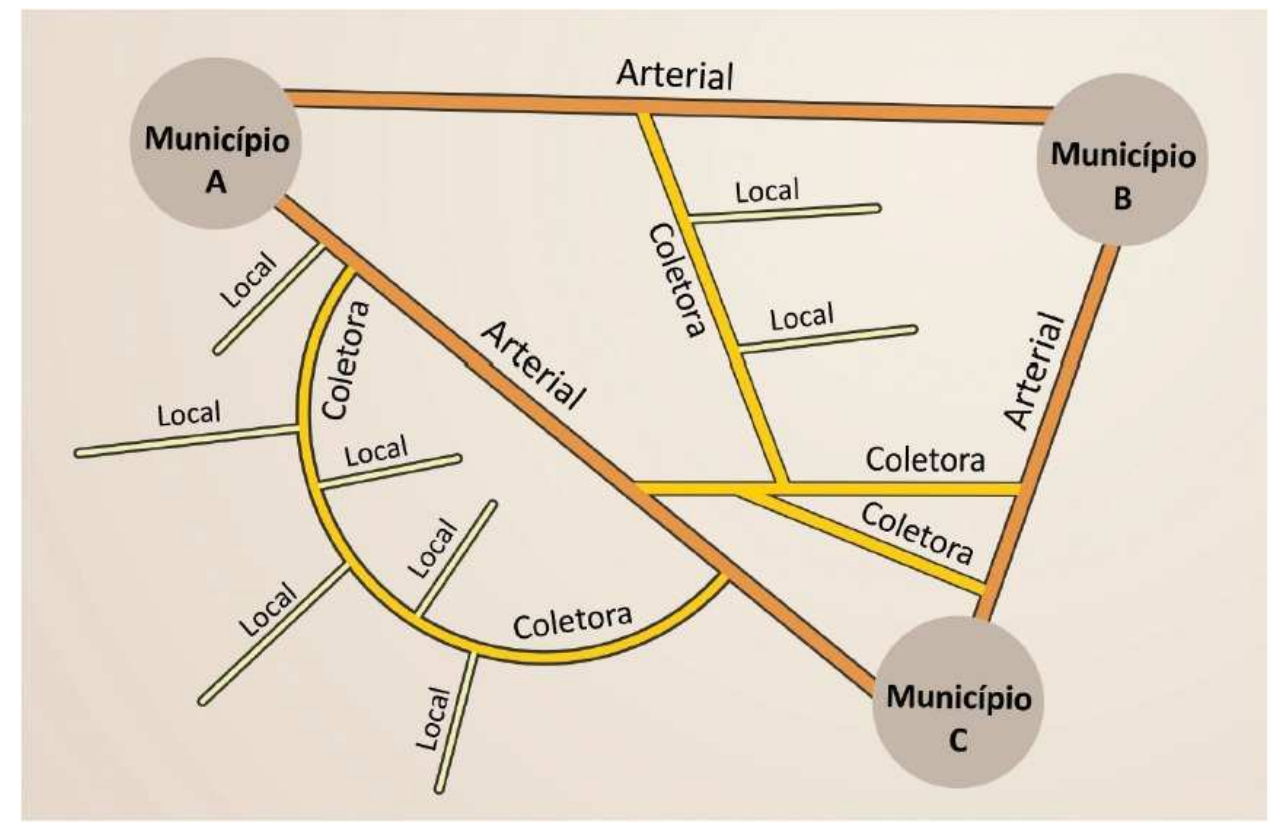

Figura 2: Topologia e classificação funcional de rodovias rurais Fonte: São Paulo (2012)

Sendo a funcionalidade um critério comum aos dois documentos optou-se pelo seu uso na classificação do sistema viário que serve aos assentamentos. Por efectuar a conexão das vias locais a uma via arterial secundária, as três principais vias foram classificadas como vias coletoras.

Os dados e informações obtidos durante as visitas técnicas e trabalho de campo foram tratados estatisticamente com auxílio do Software EXCEL e posteriormente inseridos e tratados nos SIG: ARCGIS 9.3 (de código fonte fechado) e Quantum GIS, versão Lisboa (de código fonte aberto). A imagem de caracterização do relevo foi obtida após confecção do mosaico das imagens SRTM fornecidas gentilmente pela Empresa Brasileira de Pesquisa 
Agropecuária - EMBRAPA (MIRANDA, 2013). Após construção, a paleta de cores do mosaico foi redefinida em SIG.

\section{Resultados e discussão}

A capacidade populacional total estimada pelo INCRA para os três assentamentos é de aproximadamente 1250 famílias. Algumas dessas famílias assentadas estão distribuídas ao longo das estradas e rios que cortam os assentamentos, com destaque para o rio Tartarugalgrande e os pequenos rios que formam sua bacia. Entretanto a maior parte da população está concentrada em cinco agrovilas, sendo quatro no PAE Cedro: Vila do Cedro, Vila Entre Rios, Vila Progresso e Vila do Mutum. No assentamento Bom Jesus dos Fernandes a vila homônima. Todas as vilas são servidas por uma linha de distribuição de energia que quase sempre segue o mesmo percurso das principais rodovias existentes no interior dos assentamentos. As vilas do Cedro e Bom Jesus são as maiores e melhor organizadas, contando com escolas, igrejas, centros comunitários, sistemas de distribuição de água e iluminação pública.

\subsection{Aspectos físicos}

O relevo que configura os assentamentos é constituído na porção leste pelas colinas do Amapá com altitudes médias que na área dos assentamentos, variam entre 40 e 107 metros aproximadamente. Esse relevo ondulado de topo bastante aplainado ocorre sobre terrenos terciários formando vales encaixados que constituem uma drenagem abundante. Em pontos mais interiores, sobre a capa florística de transição entre o cerrado e a floresta latifoliada, as altitudes podem chegar a um pouco mais de 200 metros (Figura 3). 


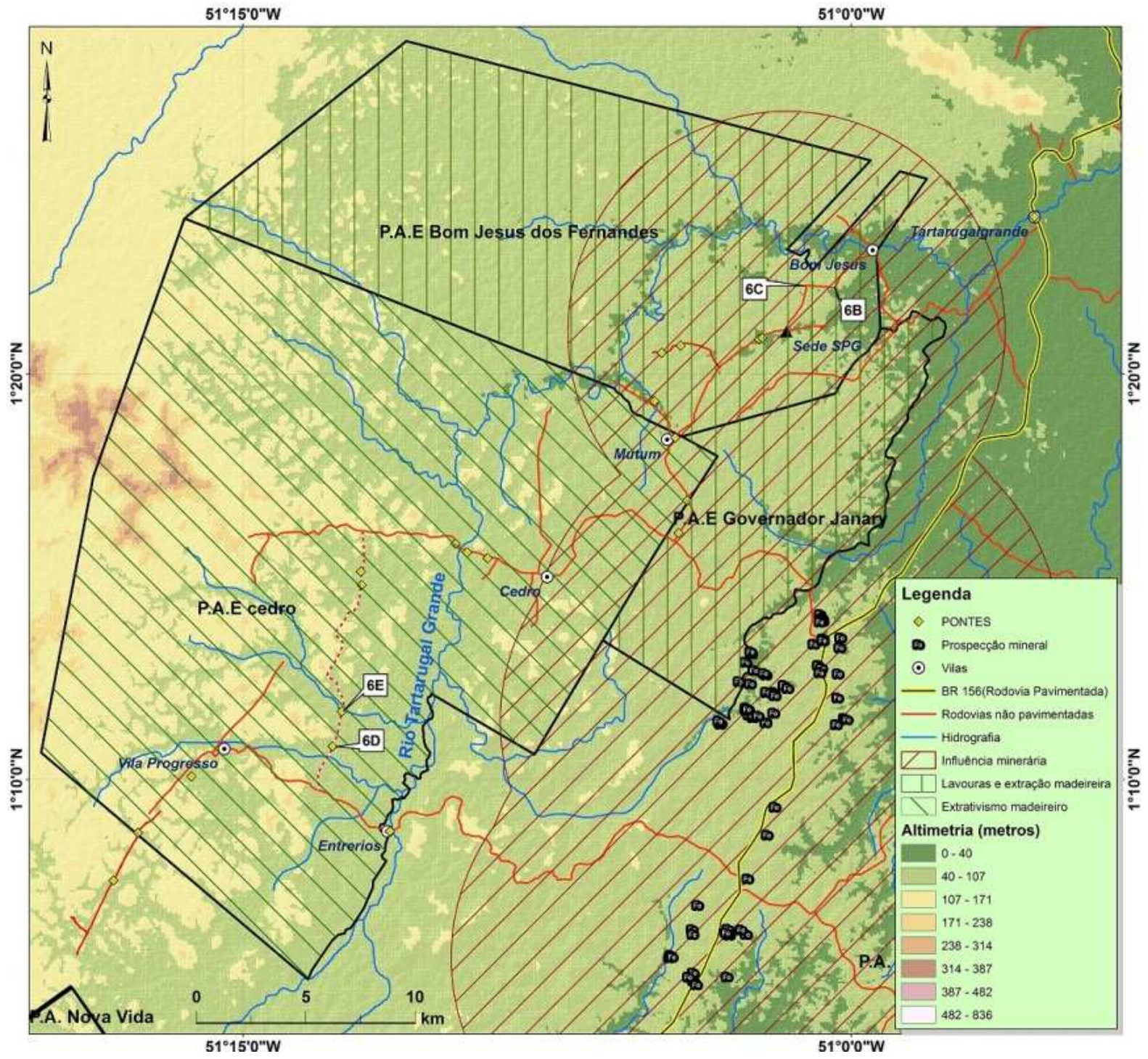

Figura 3: Usos preponderantes do solo, rede viária, características altimétricas do relevo e hidrografia, nos assentamentos Cedro, Bom Jesus dos Fernandes e Governador Janary.

A oeste ocorrem serranias de baixas altitudes que fazem parte do planalto dissecado do norte do Amapá, essas formações alcançam cotas um pouco acima dos 300 metros de altitude. Essa é a única porção do relevo classificado como acidentado na área dos assentamentos (AMAPA, 2008) compreendendo dois pequenos corredores de montanhas com topos de crista nas direções sudoeste/nordeste. Essas formações estendem-se sobre um prolongamento dos terrenos da crosta antiga até o contato com a formação terciária.

O rio Tartarugalgrande é o principal curso d'água da rede hidrográfica que drena o conjunto de assentamentos. Esse rio deságua na região dos grandes lagos no leste do estado e em seu alto curso corta os três assentamentos agroextrativistas correndo em sentido sudoeste/nordeste. O Tartarugalgrande forma uma rede dentrítica que verte as águas a 
partir de dois grandes divisores, um a leste constituído pelas colinas do Amapá e outro a oeste formado pelo conjunto de serranias de baixas altitudes, residuais dos planaltos dissecados do centro/norte (Figura 3).

A geologia local está compreendida na porção oeste por terrenos da crosta antiga, constituidos por rochas gnáissicas, migmatitoss, granitóides e pegmatios de complexos arqueanos (SPIER e FERREIRA FILHO, 1999). Esses terrenos que se dispõe sob a cadeia de serranias centrais são compostos por rochas com grande potencial mineralógico. Ao centro ocorrem os terrenos transicionais entre a crosta antiga e o terciário, também com grande potencial mineralógico. A leste ocorre a formação barreiras propriamente, são sobre esses terrenos sedimentares terciários que ocorre a formação florística do cerrado (savana) amapaense (AMAPA, 2008).

\subsection{Formas tradicionais e novas formas de uso do solo em assentamentos rurais no}

\section{Amapá}

O extrativismo de PFNM, agricultura e pecuária de subsistência, há muito tempo, configuram-se como formas tradicionais de uso dos solos na Amazônia e também em terras amapaenses. Essas formas de uso do solo, também passaram a caracterizar-se como as principais atividades produtivas durante o processo de criação e implantação dos PAE no Amapá. Desde a criação desses assentamentos rurais, ainda na década de 80 do século XX, as primeiras famílias beneficiadas pelo processo de regularização fundiária, já praticavam em suas terras essas atividades.

Na maioria dos casos, a criação dos $\mathrm{PAE}$, foi apenas uma maneira de regularizar a situação fundiária de pequenos produtores rurais. Regra geral, os "assentados", há muito desenvolviam atividades de subsistência nas terras onde foram criados e implantados os assentamentos rurais. Esse "cercamento", por assim dizer, ocorreu principalmente no sul e oeste do estado e posteriormente estendeu-se para outras regiões onde de fato pouco se praticava atividade extrativista florestal ou lavoura de subsistência.

A área onde foi implandado o conjunto de PAE em Tartarugalzinho apresenta características de apropriação e uso do solo, bem diferenciada. Esse conjuto de Assentamentos foi criado para de fato, receber e alocar famílias deslocadas de outros lugares do estado e até mesmo de fora deste, que pouco se identificavam com as atividades extrativas, pressupondo-se sua 
vocação para o desenvolvimento de atividades produtivas voltadas para a agricultura e/ou pecuária.

O esforço inicial do INCRA e dos assentados foi a priorização do uso do solo através da implantação de Sistemas agroflorestais. Os SAF nesse conjunto de assentamentos estão voltados para cultivos permanentes de frutas, como laranja, cupuaçu e graviola ou cultivos temporários de frutas como banana, abacaxi, açaí (Figura 4) e tubérculos regionalmente consumidos in natura como a macaxeira e a mandioca, utilizada para fazer farinha dágua e tucupi, insumos alimentares que fazem parte da culinária local e, portanto, teriam grande aceitação local. Entretanto, ao que tudo indica , o baixo desempenho das vendas, a falta de planeamento ou adequação desse planeamento e de informações sobre o mercado, acabaram por levar a uma gradativa frustração da produção de excedentes nos SAF, cujo objetivo era sustentar-se a partir dessas vendas no mercado local.

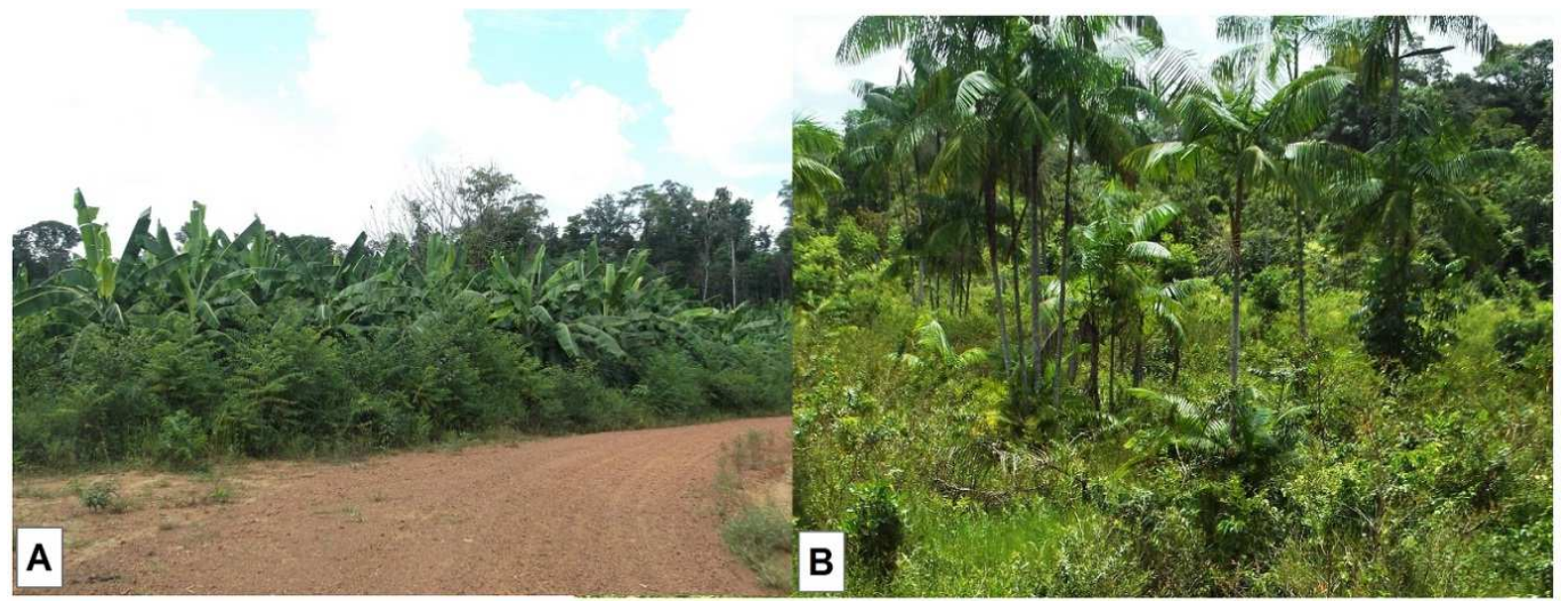

Figura 4: Sistemas agroflorestais com cultivo de banana (A) no PAE B.Jesus dos Fernandes e açai (B) no PAE Cedro

Assim como em outros assentamentos no Amapá, a renda média dos assentados quase sempre está vinculada ao que é produzido através dos Sistemas Agro-florestais. De acordo com Moraes (2011) ao avaliar a eficiência econômica de SAF de cultivos temporários e permanentes, constatou que nos anos iniciais, os custos de manutenção em ambos os casos , tornam os custos totais superiores aos benefícios financeiros. Portanto, do ponto de vista económico, mesmo em situações onde há forte tradição no uso do solo com SAF, esses sistemas só são viáveis com adequado planeamento e sólidos investimentos. 


\begin{tabular}{c|c|c|c|c}
\hline SAF & $\begin{array}{c}\text { Área média } \\
\text { aproximada de } \\
\text { plantio* } \\
\text { (Hectare) }\end{array}$ & $\begin{array}{c}\text { Renda média } \\
\text { mensal } \\
\text { (bruta) } \\
\text { US } \mathbf{\$ *}^{* *}\end{array}$ & $\begin{array}{c}\text { Renda média mensal } \\
\text { líquida (abatidos os } \\
\text { custos de manutenção } \\
\text { de 40\%) } \\
\text { US } \mathbf{* * *}\end{array}$ & $\begin{array}{c}\text { Renda média } \\
\text { mensal per capta } \\
\text { (líquida)**** } \\
\text { US } \mathbf{\$}^{* *}\end{array}$ \\
\hline $\begin{array}{c}\text { Cultivos } \\
\text { permanentes }\end{array}$ & 3,6 & 834,96 & 500,98 & 131,83 \\
\hline $\begin{array}{c}\text { Cutivos } \\
\text { temporários/sa } \\
\text { zonais }\end{array}$ & 2,5 & 477,15 & $\mathbf{2 8 6 , 2 9}$ & $\mathbf{7 5 , 3 3}$ \\
\hline Totais & $\mathbf{6 , 1}$ & $\mathbf{1 3 1 2 , 1 1}$ & $\mathbf{7 8 7 , 2 7}$ & $\mathbf{2 0 7 , 1 7}$ \\
\hline
\end{tabular}

Tabela 1: Renda média por área cultivada em um SAF no Amapá

Fonte: Adptado de Maciel (2014); De Matos (2005); DIEESE (2011); Arco-Verde e Amaro (2011)

* Conforme dados coletados por Maciel (2011) durante avaliação de Sistemas Agroflorestais

** Valor médio do US\$ no segundo semestre do ano de 2013, ano da pesquisa realizada por Maciel (2014). Disponível em http://www4.bcb.gov.br/pec/taxas/port/ptaxnpesq.asp?id=txcotacao.Acesso em 28/01/2016.

*** Conforme avaliação feita por De Matos (2005) e Arco-Verde e Amaro (2011)

****A considerar o número de 3,8 pessoas por família (DIEESE,2011).

Segundo Maciel (2014), no Amapá, em aproximadamente 6,1 hectares de solo em SAF com cultivos permanentes e temporários, abatidos os custos de manutenção, a renda média mensal gira em torno de US\$ 787,27. A considerar que o grupo familiar na região norte do país é constituído, segundo o DIEESE (2011) por 3,8 pessoas, a renda média per capta resultante da conjugação de cultivos permanentes e temporários em SAF nos assentamentos do Amapá gira em torno de US\$207,17 mensais (Tabela 1).

Deve-se, entretanto salientar que nem sempre os cultivos permanentes e temporários estão presentes nas propriedades dos assentados e mesmo quando estão, a produtividade depende da perfeita disponibilidade de recursos para a sua manutenção. Infere-se, portanto, que essa é uma renda mensal em condições normais de produção, sujeita a variar em função de fatores físicos como o clima ou sócio-económicos como a falta de recursos financeiros e insumos para manutenção.

No caso do conjunto de assentamentos do Cedro, Bom Jesus dos Fernandes e Governador Janary essas condições apresentam certa especificidade. Ao que tudo indica, nesses assentamentos, os SAF depois de implantados, se tiveram um planeamento, parece não ter sido adequado às variáveis benefício/custo, de maneira a impedir sua consolidação de fato nos anos posteriores a sua implantação. Ainda que existissem linhas de crédito que pudessem servir para financiar a manutenção ou aumento e diversificação da lavoura, esses recursos só poderiam ser liberados após a apresentação às entidades financiadoras, de um projeto adequado a cada realidade. 
A exigência de projetos de financiamento para pequenos agricultores em assentamentos é um dos grandes gargalos ao desenvovimento das comunidades nele assentadas, uma vez que quase a totalidade das pessoas, não possui escolarização (DIEESE,2011) ou conhecimento técnico necessário para elaborar documentos com a complexidade que se exige em um projeto, ainda que este requeira critérios mínimos para sua viabilização. Ademais, o auxílio que poderia ser dado pelos técnicos do INCRA ou outra instituição voltada para a assitência rural, quase sempre se restringe a uns poucos assentados, uma vez que estes se distribuem nos PAE, que tem grandes extensões. Na maioria dessas propriedades o acesso é dificultado por um sistema de rodovias mal planeadas, com manutenção precária e totalmente dependende das verbas públicas federais. Essas verbas, administradas pelo INCRA, são utilizadas para resolver problemas nos assentamentos sob supervisão do órgão em todo o estado Amapá.

As péssimas condições de acesso e mobilidade do sistema rodoviário interno aos assentamentos estão, portanto, em grande medida, relacionadas à ineficácia no uso do solo para cultivos nos SAF. A frustação das receitas que estes cultivos poderiam gerar reverteuse na depreciação gradativa da qualidade de vida dos assentados. Isso também levou ao sucateamento das estruturas implantadas e ao que se percebe, na acomodação de um modelo de subsistência em torno de umas poucas lavouras em Sistemas agroflorestais de baixa eficiência económica.

Recentemente o conjunto de PAE do Cedro, Bom Jesus dos Fernandes e Governador Janary, também acabaram por ver instalarem-se outras atividades produtivas como a mineração industrial e a extração madeireira em escala comercial, que até pouco tempo não eram cogitadas para serem desenvolvidas nesses modelos de assentamentos rurais. No caso específico da mineração, no conjunto de assentamentos, Cedro Governador Janary e Bom Jesus dos Fernandes, essa atividade está claramente instituída com apoio formal da Secretaria de Estado do Meio Ambiente do Amapá (SEMA-AP), que assina a concessão de licença ambiental para pesquisa na região. Embora a maior parte dessas pesquisas esteja concentrada em áreas de propriedade da SPG Mineração, no entorno dos assentamentos, alguns dos pontos de prospecção para a pequisa mineral se encontram no interior da área dos assentamentos Governador Janary e Bom Jesus dos Fernandes (Figura 3).

A pesquisa mineral com o objetivo de extração futura do minério de ferro tem sido realizada desde 2006. Desde aquele ano, a SPG Mineração, empresa mineralógica sediada em Macapá, registrou no Departamento Nacional de Pesquisa Mineral (DNPM) sete lotes de terra, num total de 436,23 $\mathrm{km}^{2}$ para fins de mineralogia (SPG MINERAÇÃO, 2013). Apesar de 
grande parte dos pontos de pesquisa estarem no entorno, a sede de apoio logístico da mineradora está situada no interior do PAE Bom Jesus dos Fernandes, na estrada que liga a Vila de Bom Jesus à localidade do Mutum (Figura 3).

As áreas informadas pela SPG Mineração ao DNPM como sendo de sua propriedade compreendem o entorno leste dos PAE Cedro, Governador Janary e Bom Jesus dos Fernandes. As perspectivas de implantação de um polo mineralógico trazem tanto a expectativa de investimentos quanto de impactos físico-ambientais e socioeconómicos. Do ponto de vista físico esses impactos poderiam afetar diretamente toda a área compreendida pela bacia hidrográfica do rio Tartarugalgrande. Embora os impactos indiretos no meio físico sejam mais difíceis de serem estimados, os impactos diretos afetariam as populações dos três assentamentos. Essa área de impacto, calculada através do traçado de uma linha de entorno de $10 \mathrm{~km}$ a partir dos pontos de pesquisa mineral informados pela SPG até 2010 compreende aproximadamente $1105 \mathrm{~km}^{2}$, num polígono que se estende no sentido sulnorte (Figura 3, área em destaque com linhas diagonais em cor marron).

A extração madeireira já consolidada vem sendo praticada por inúmeros empresários madeireiros que atuam principalmente no comércio de madeira a varejo de Macapá e Santana, municípios cujas sedes são as duas cidades mais populosas do Amapá. Entre 2011 e 2013, foram formalizadas junto ao INCRA para o PAE Cedro, 28 solicitações de projetos de extração madeireira (Tabela 2).

\begin{tabular}{|c|c|c|c|c|c|c|c|}
\hline \multirow{3}{*}{$\begin{array}{c}\text { Projetos de } \\
\text { Assentamento }\end{array}$} & \multicolumn{6}{|c|}{ APATS deferidas } & \multirow{3}{*}{$\begin{array}{c}\text { Total de APATS } \\
\text { deferidas }\end{array}$} \\
\hline & \multicolumn{2}{|c|}{2011} & \multicolumn{2}{|c|}{2012} & \multicolumn{2}{|c|}{2013} & \\
\hline & [1] & [2] & [1] & [2] & [1] & [2] & \\
\hline Cedro & 15 & 1 & 7 & 1 & 1 & 3 & 28 \\
\hline No Amapá & 34 & 24 & 28 & 2 & 5 & 8 & 119 \\
\hline
\end{tabular}

[1] Sem plano de manejo

[2] Com plano de manejo

Tabela 2: Comparativo das solicitações de Autorizações para a extração de madeira no PAE Cedro e no estado do Amapá.

Fonte: Dados fornecidos pelo escritório regional do INCRA no Amapá.

A quantidade de autorizações de extração madeireira deferidas no PAE Cedro representam $23,52 \%$ do total de autorizações realizadas para os Projetos de Assentamentos rurais em todo o estado do Amapá. Desse total, 70\% representam autorizações onde não há plano de manejo definido, ou este está em construção e apenas os 30\% restantes das solicitações contemplam um plano de manejo. A existência do plano de manejo significa a definição de 
parâmetros que permitam retirar a madeira da floresta nativa com o mínimo de impactos ambientais e seguindo procedimentos que permitam a manutenção das condições de recomposição da floresta.

Embora a exigência do plano de manejo seja uma das condições necessárias para a obtenção da licença de extração madeireira, em muitas áreas o manejo é realizado de forma bastante precária, com pouca preocupação com a capacidade de regeneração da floresta ou conservação dos solos. No interior dos assentamentos isso parece ser reflexo da ausência de assistência técnica especializada que permita aos assentados retirar a madeira com técnicas apropriadas e de forma racional. Em função do objetivo final dos PAE, que é o desenvolvimento social e econômico aliado à conservação da natureza, faz-se necessário conjugar a extração da madeira com o aproveitamento da biomassa da floresta como subsídio físico à utilização dos solos para posterior implantação de sistemas de cultivos agroflorestais.

Mas a retirada predatória da madeira das florestas no interior dos assentamentos tem sido inclusive incentivada com a abertura de novos pequenos trechos de estradas. Um desses trechos possui aproximadamente $4 \mathrm{~km}$ de extensão e foi aberto com auxílio da Mineradora SPG (Figura 5). Esse ramal foi aberto em meio a uma área florestada no trecho da rodovia que liga as Vilas Bom Jesus dos Fernandes e Mutum. Essa pequena estrada foi implantada no interior do Assentamento Bom Jesus, onde não existem autorizações formalizadas junto ao INCRA, para a extração madeireira, mas onde se constatou a retirada e beneficiamento primário (Figura $5 \mathrm{~A}$ ).

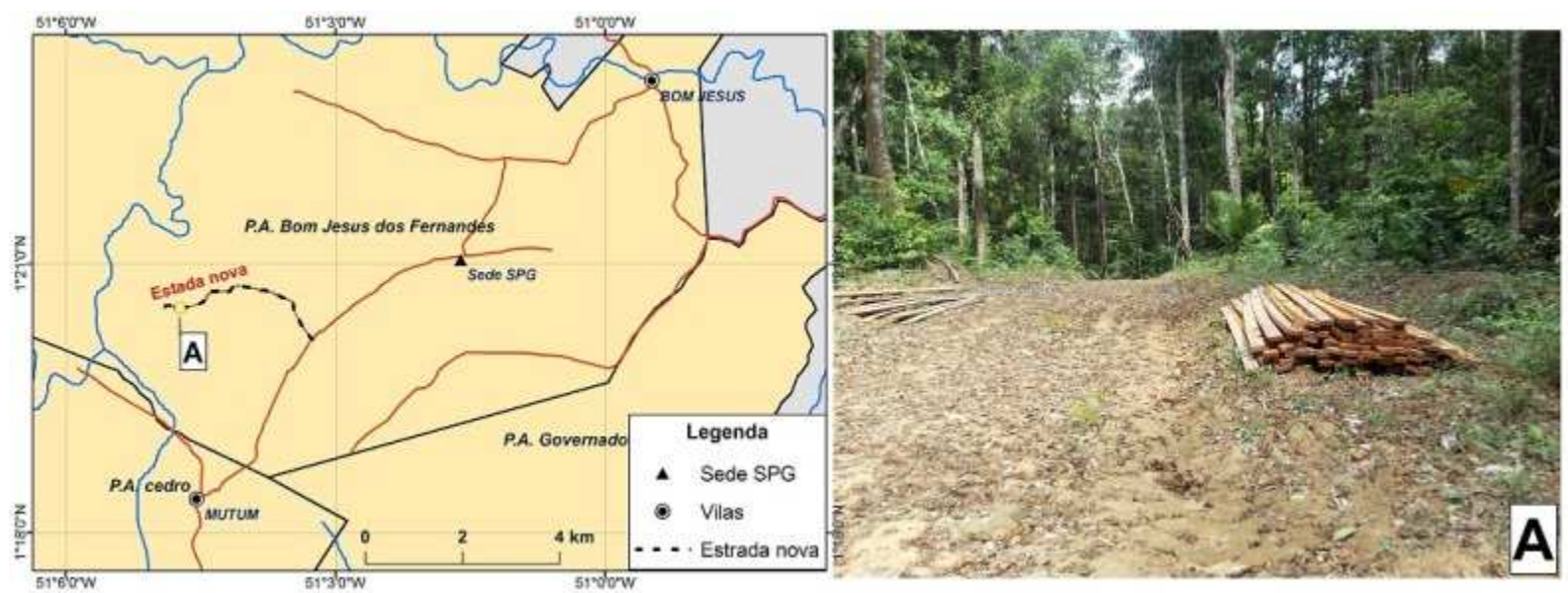

Figura 5: Madeira semi-beneficiada retirada em estrada nova, aberta pela SPG Mineração no Assentamento Bom Jesus dos Fernandes.

Esses registros da extração ilegal de madeira demonstram a interface construída entre as atividades madeireira e mineral no que concerne à apropriação produtiva nos 
assentamentos. Essa sinestesia entre as atividades extrativistas, pode representar uma nova forma de apropriação da terra nos assentamentos, que tende a consolidar-se na medida em que as demandas dos mercados justificarem um aporte maior de recursos. Localmente, as perspectivas econômicas e sociais dependem de como os assentados e órgãos fiscalizadores como INCRA e Secretaria Estadual do Meio Ambiente (SEMA-AP) irão interagir no contexto dessa apropriação.

Ainda que haja incertezas quanto aos impactos sociais e ambientais que as atividades extrativas da indústria madeireira e mineral estejam a causar ou ainda possam vir a causar, em geral, as duas abrem possibilidades de renda mais substanciais que aquela gerada com o uso do solo em Sistemas Agloflorestais. De acordo com dados do DIEESE (2014) a renda média mensal do trabalhador na indústria mineral era de aproximadamente US\$ 2410,26. Já na atividade extrativa com manejo florestal, Franco e Esteves (2008) ao avaliar duas experiências em PAE do estado do Acre, constataram que a renda líquida média mensal com venda de madeira manejada foi de aproximadamente US\$1550,34 (Tabela 3).

\begin{tabular}{|c|c|c|c|}
\hline Atividade produtiva & $\begin{array}{c}\text { Renda média } \\
\text { US\$* }\end{array}$ & $\begin{array}{c}\text { Renda média per } \\
\text { capta** } \\
\text { US\$ }\end{array}$ & $\begin{array}{c}\text { Diferença de renda média per capta } \\
\text { em \% entre uso tradicional (B) e } \\
\text { novos usos do solo (A,C) }\end{array}$ \\
\hline $\begin{array}{c}\text { Extração de madeira } \\
\text { manejada }\end{array}$ & 1550,34 & 407,98 & \multirow{2}{*}{49,23} \\
\hline $\begin{array}{c}\text { (B) } \\
\text { Cultivo em SAF }\end{array}$ & 787,27 & 207,17 & \\
\cline { 1 - 2 } (C) & 2410,26 & 634,27 & \\
\cline { 1 - 2 } $\begin{array}{c}\text { Extrativismo mineral } \\
\text { industrial }\end{array}$ & & 67,34 \\
\hline
\end{tabular}

Tabela 3: Renda média obtida e comparativo da diferença percentual de renda entre atividade de uso tradicional do solo (SAF) e novos usos (Extrativismo madeireiro e mineral) .

Fonte: Adptado de Maciel (2014); Franco e Esteves (2008); De Matos (2005); DIEESE (2011,2014); Arco-Verde e Amaro (2011).

*Valor médio do US\$ no segundo semestre do ano referente ao período apresentado nas fontes consultadas. Disponível em http://www4.bcb.gov.br/pec/taxas/port/ptaxnpesq.asp?id=txcotacao. Acesso em 28/01/2016.

**Considerando o número de 3,8 pessoas por família (DIEESE 2011).

Quando se considera apenas a capacidade de agregação de renda, as atividades extrativistas industriais ou de larga escala (que imprimem novos usos do solo) possibilitam aumento significativo de renda para a população local em relação ao cultivo em SAF, forma tradicional de uso do solo. Na atividade extrativa de madeira manejada, o acréscimo de renda, mesmo quando se considera apenas uma pessoa a trabalhar no grupo familiar médio de 3,8 pessoas (DIEESE, 2011) pode agregar-se até 49,23\% em relação ao valor da renda per 
capta obtida no uso tradiconal com cultivo em SAF. Na atividade extrativa mineral com apenas uma pessoa no grupo familiar empregada a renda per capta pode ser de até $67,34 \%$ maior do que a obtida no cultivo em SAF (tabela 3).

\subsection{Caracterização e condição atual da rede viária nos assentamentos do Cedro, Bom} Jesus dos Fernandes e Governador Janary.

A rede viária terrestre nos assentamentos soma aproximadamente $155 \mathrm{~km}$ de extensão de rodovias não pavimentadas, quase todas implantadas com pouca ou nenhuma adição de camada de material sobre o leito natural. Essa rede corresponde aproximadamente $40 \%$ do total das estradas do município de Tartarugalzinho que é de aproximadamente $400 \mathrm{~km}$.

Os assentamentos do Cedro, Bom Jesus e Governador Janary por serem adjacentes possuem uma rede viária traçada inicialmente para proporcionar a sua interligação. De acordo com as definições do Projeto Geométrico de Estradas Rurais (BRASIL, 1999) a rede de rodovias interna aos assentamentos pode ser classificada, de acordo com sua funcionalidade em três pequenos sistemas coletores conectados à rodovia BR 156 que funciona como uma via arterial (expressa) secundária (Figura 6).

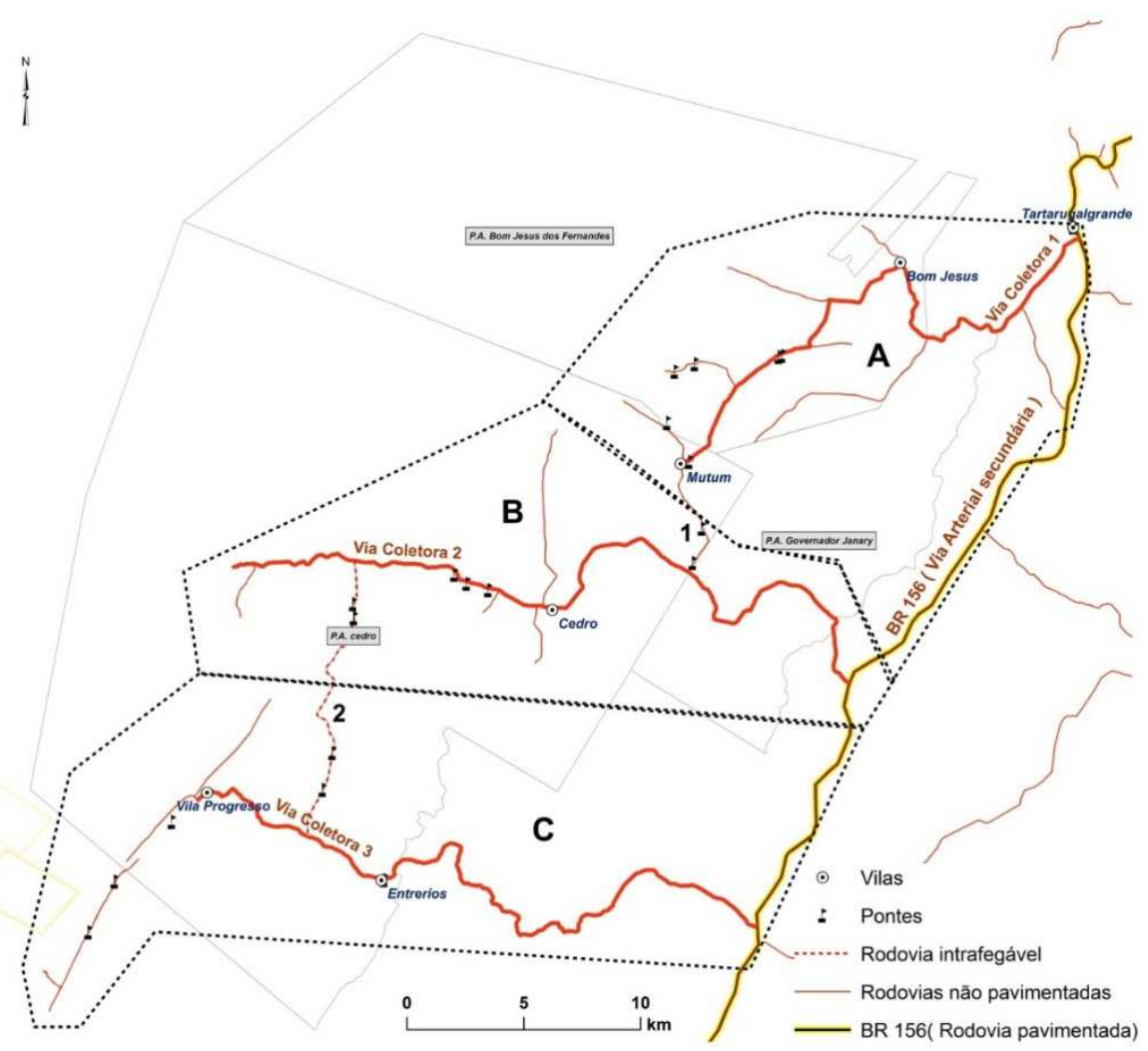

Figura 6: Topologia e classificação do sitema viário nos assentamentos Cedro, Bom Jesus dos Fernandes e Governador Janary. 
O primeiro sistema coleta fluxos de pequenas vias nos Assentamentos do Bom Jesus dos Fernandes e Cedro ligando as vilas do Mutum e Bom Jesus dos Fernandes a BR 156 e à Via Coletora 2 (Figura 6, polígono A). O segundo sistema coleta fluxos de pequenas vias locais nos assentamentos Govenador Janary e Cedro, e conecta a Vila do cedro a BR 156 e à Via Coletora 1 (Polígono B). O terceiro sistema coleta fluxos de vias locais no Assentamento do Cedro e conecta as vilas de Entrerios e Progresso entre sí e à BR 156 (Polígono C).

Os três sistemas Coletores foram projetados para serem inteconectados através de duas pequenas vias locais (Figura 6, linhas 1 e 2), mas em função da intrafegabilidade da estrada local 2 (Figura 6, Linha 2) que deveria conectar os sistemas Coletores B e C, essa conectividade não pode ser realizada atualmente, comprometendo os fluxos intraassentamentos.

Cortadas pelo rio Tartarugalgrande e seus tributários as estradas possuem 19 pontes sobre os trechos onde a drenagem é muito significativa. Essas pontes, todas construídas em madeira, tem extensões que variam entre 3 e 30 metros. Dadas às precárias condições de sua manutenção (Figura 7 D e E), apenas 11 pontes nos sistemas Coletores A e B e 4 pontes no sistema Coletor $C$, permitem o tráfego de veículos durante o período de estiagem que ocorre entre os meses de agosto a setembro. No período chuvoso, que ocorre entre os meses de dezembro a junho, em função da deterioração do terrapleno das vias esse tráfego é realizado de forma bastante precária sendo eventualmente interrompido por determinados intervalos de dias (Figura 7, B e C).

Dos $155 \mathrm{~km}$ de rodovias internas aos assentamentos, aproximadamente 100 constituem vias em estado geral bastante precário, cuja manutenção é realizada com pouca técnica e muito boa vontade da população. Essa manutenção é realizada através de operações tapa-buracos com adição de "piçarras" (pedras de pequenas dimensões extraídas nas áreas de cerrado próximas). Esse material é coletado em terrenos terciários ricos em laterita ferruginosa e transportado durante o período chuvoso (inverno) até as partes mais afetadas pela erosão hídrica nas estradas (Figura 7, B e C). 

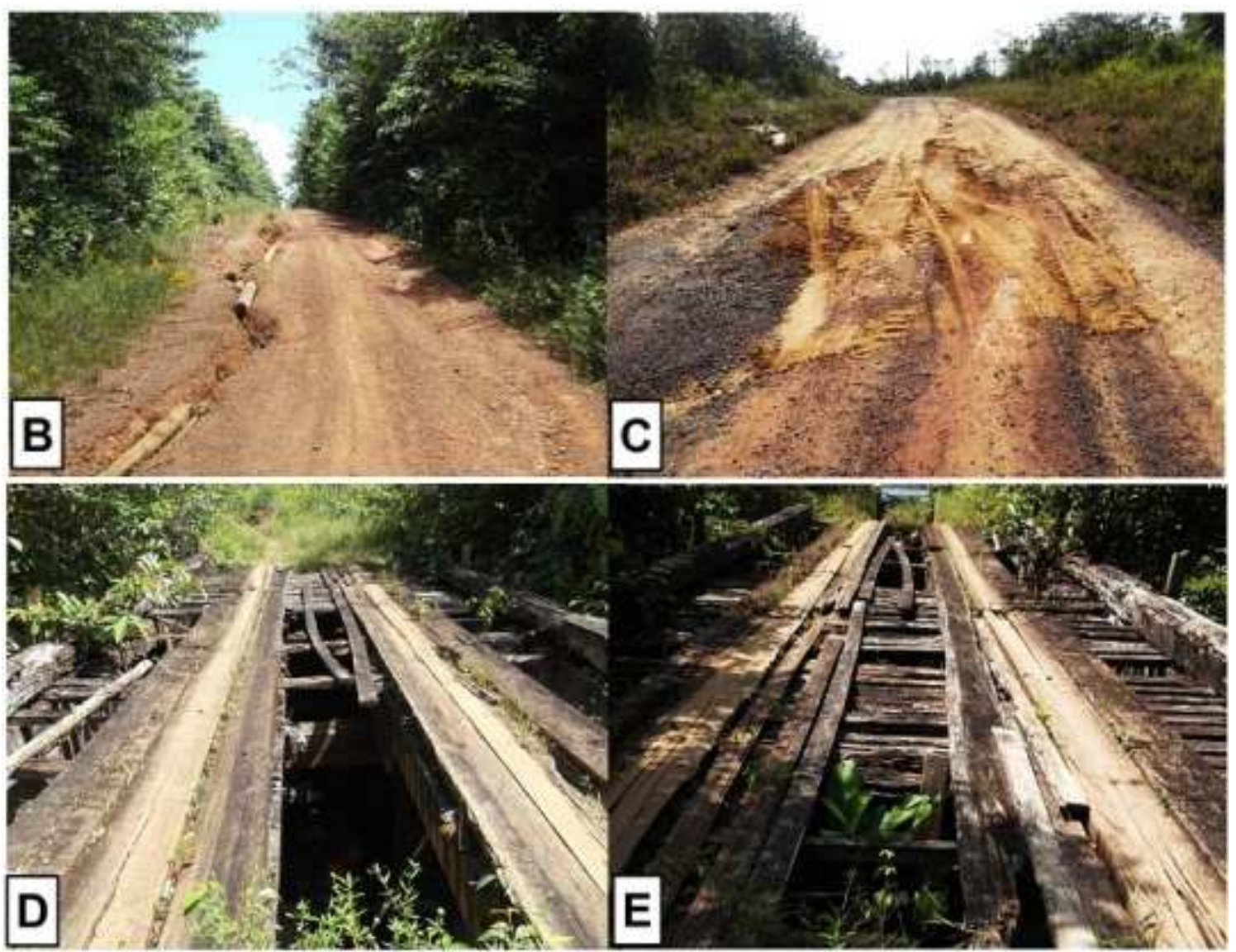

Figura 7: Estado geral de manutenção nas estradas e pontes no sistema viário dos assentamentos.

As rodovias Coletoras, que propiciam o acesso às principais vilas foram abertas sobre terrenos terciários através do descapeamento do cerrado nativo. O solo laterítico e o relevo suavemente ondulado proporcionou a abertura de estradas que oferecem boas condições de manutenção, com largura de aproximadamente 6,5 metros para a rodovia do cedro e 6,3 metros para a rodovia que leva à Vila de Bom Jesus (Figura 8 A).

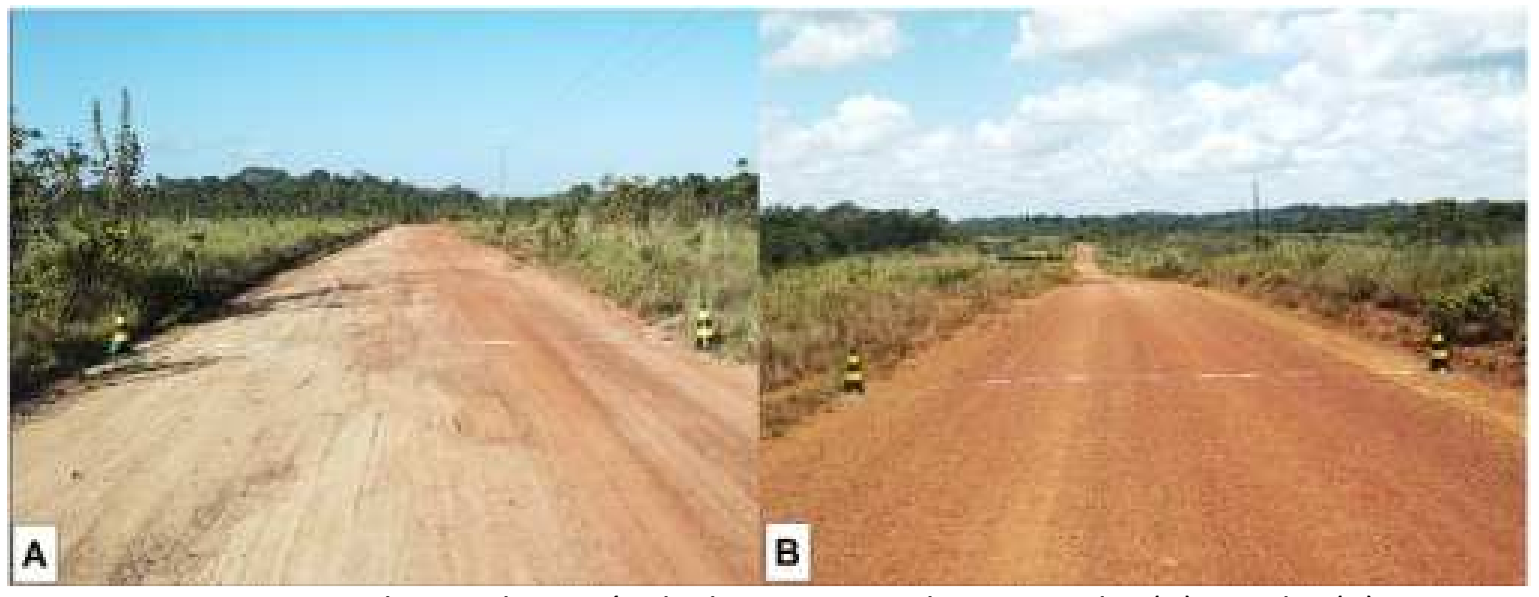

Figura 8: Estradas que levam á Vila de Bom Jesus dos Fernandes (A) e Cedro (B). 
O início da rodovia Coletora 1 que leva à Vila de Bom Jesus dos Fernandes fica na rodovia BR 156 a apenas 600 metros ao sul da Vila de Tartarugalgrande. Esse trecho tem uma extensão de $13 \mathrm{~km}$ e é cortado por um pequeno riacho que faz parte da bacia hidrográfica do rio Tartarugalgrande. Sobre esse riacho, situado a aproximadamente $5 \mathrm{~km}$ do início da rodovia há uma ponte construída em madeira com 3 metros de largura por 8 de extensão. A ponte apresenta boas condições de trafegabilidade para veículos de pequeno porte, entretanto, dada a imprecisão das condições atuais da estrutura, a possibilidade de um aumento da carga requer um estudo de avaliação de impacto.

A rodovia coletora 2 que leva à vila do Cedro, desde o início na BR 156 até a entrada da vila tem uma extensão de 10,5 km. O início dessa rodovia fica a uma distância de $11 \mathrm{~km}$ da Vila de Tartarugalgrande e a $35 \mathrm{~km}$ da cidade de Tartarugalzinho (Figura 8B).

O estado de manutenção relativamente satisfatório das rodovias coletoras, principais vias dos assentamentos do Cedro, Bom Jesus dos Fernandes e Governador Janary acontece apenas até as vilas. Os trechos restantes encontram-se em situações bastante diferenciadas de manutenção, mas em geral apresentam características que denotam o relativo estado de abandono. As larguras não ultrapassam os 3 metros em grande parte do traçado, por falta de manutenção periódica em seu terrapleno essas estradas apresentam muitas ravinas em quase toda extensão, acentuando-se nos trechos de maior inclinação do relevo do terreno onde foram abertas (Figura $7 \mathrm{~B}$ e $\mathrm{C}$ ).

A rodovia local que deveria fazer a ligação entre a Rodovia Coletora 2 no Cedro e a Rodovia Coletora 3 entre as Vilas de Entrerios e Progresso, apresenta-se em estado intrafegável e de completo abandono (Figura 4, Linha 2). Essa via, com aproximadamente $11 \mathrm{~km}$ de extensão, corta o assentamento do cedro nas direções norte/sul, sob um relevo relativamente plano nas extremidades e com angulações consideráveis em sua parte central. Todas as pontes nessa estrada estão completamente interditadas para o tráfego de veículos, com a madeira da estrutura em estado de completa deterioração.

No interior da área dos assentamentos foram registrados $15 \mathrm{~km}$ de vias não catalogadas no mapeamento viário do Amapá em 2010. Desse total 4,2 km são de estradas com pequena largura, abertas de forma precária apenas com a retirada da capa de vegetação e raspagem do horizonte "A" do solo (Figura 7C). O restante da extensão de estradas registradas $(10,8$ 
$\mathrm{km}$ ) corresponde a um trecho aberto a partir do limite sul do assentamento Cedro. Esse trecho adentra a Floresta Estadual de Produção (FLOTA) e termina às margens de um riacho que constitui o limite de uma área demarcada com piquetes e arame, a sinalizar a existência de uma propriedade privada no interior dessa unidade de conservação.

Os limites da FLOTA foram inicialmente traçados de forma a garantir uma circunscrição que permitisse que essa unidade de conservação servisse como corredor ecológico. Esse imenso corredor funciona também como área de amortecimento para grandes unidades de conservação de proteção integral como os PARNA Montanhas do Tumucumaque e Cabo Orange e grandes UCs de uso sustentável como a RDS Iratapuru e a FLONA. Entretanto, ao que tudo indica, a existência de propriedades como a fazenda encontrada dentro desses limites, próximo aos assentamentos, pode revelar a falta de critérios de exclusão de áreas já apropriadas, ou ainda a ineficácia de fiscalização na FLOTA. Pesam ainda, a grande extensão de terras protegidas e a carência de recursos humanos e logísticos.

\section{Considerações finais}

O processo de construção do espaço nos assentamentos configura-se como um mosaico que expressa formas tradicionais e novas formas de uso do solo, mas com pouca coesão no que concerne às medidas que incentivem a melhoria na qualidade de vida dos assentados. De um lado a relativa inércia produtiva no conjunto de assentamentos está em boa medida, relacionada à ineficácia no modelo de planeamento e gestão, tanto da estrutura administrativa dos assentamentos quanto nos Sistemas produtivos agroflorestais ainda existentes. Por outo lado, a exploraçao madeireira em escala industrial, através do manejo florestal e a exploraçao mineralógica, ainda não foram adequadamente discutidas, nem seus objetivos ou benefícios claramente partilhados com a população local.

Se há um embate velado de forças no espaço dos assentamentos, há também uma profusão de oportunidades de luta por melhoria da qualidade de vida da população local. Embora no Amapá os processos minerários e madeireiros tenham histórico de grandes impactos negativos no que concerne a agregação de valor localmente, é preciso pensar e instigar formas de apropriação mais participativas e inclusivas. A perspectiva de conjugação dos setores, madeireiro e minerário em vez de ser considerada como fator negativo sob os 
aspectos ambientais e sociais deve ser transformada no campo do debate, numa possibilidade de desenvolvimento social regional.

Deve-se assegurar um programa de desenvolvimento para esses assentamentos que permita a total participação da população local nos processos decisórios e executivos. A capacitação funcional deve ser incentivada como forma de garantir a inclusão de jovens e adultos como mão de obra local para atuar nas atividades produtivas. Os investimentos praticados de forma tradicional nos setores madeireiro e mineralógico constituem na essência, ativos pouco sustentáveis. Entretanto, essas atividades, se planeadas e instigadas a serem desenvolvidas de forma a incluir a participação ativa da população local, podem ser revestidas em possibilidades de reinvestimentos da renda gerada nos modelos mais adequados como os SAF de maneira a prover sustentabilidade social e ambiental. Deve-se, portanto, no planeamento dos PAE, considerar a atividade madeireira tradicional e mineralógica, como a base para se repensarem os investimentos necessários para se prover a inclusão e desenvolvimento social das populações locais.

Um planeamento participativo e inclusivo requer a mobilização dos diversos agentes que ordenam o território. Se nos Projetos de Assentamentos Extrativistas, as comunidades de assentados constituem o alvo da inclusão social, devem ser também o principal agente do processo. São as próprias comunidades que devem capitanear os processos de ordenamento do território, que implicarão ou poderão ser revestidos em investimentos económicos e sociais localmente.

Deve-se priorizar o estabelecimento de parcerias com as próprias empresas de extração madeireira e mineradoras, que possibilitem ampliar e melhorar a infraestrura viária, tão necessária ao desenvolvimento social e econômico nesses assentamentos rurais. Faz-se necessário, com certa urgência, de um programa que possibilite tanto a manutenção das estradas quanto das pontes que as interligam. De igual maneira, deve-se vislumbrar ainda a substituição gradativa das estruturas em madeira das pontes, por outras de maior segurança e vida útil, como as de concreto.

A responsabilidade sobre a manutenção da estrutura viária, como se pôde perceber, tem sido encampada pelos próprios assentados, ainda que de forma precária. Mas essas estruturas há muito têm servido de suporte a atividade de extração madeireira e mais recentemente à atividade mineralógica. Esses grandes agentes do processo produtivo intraassentamentos devem ter papel de destaque na manutenção e melhoria dessa estrutura 
viária, tanto pela necessidade de uso para a extração dos recursos naturais quanto pela apropriação de um bem coletivo, que pertence em primeiro plano aos assentados e cujo principal mantenedor sempre foi o Estado.

A situação atual da rede viária indica o estado dos descaminhos no processo de desenvolvimento social e econômico nos grandes Projetos de Assentamentos no Amapá, e mais especificamente no conjunto do Cedro, Bom Jesus dos Fernandes e Governador Janary. É preciso vencer a insipiência inerente ao uso atual dos recursos naturais nesses assentamentos, notadamente quando se percebe as possibilidades de agregação de renda que a extração madeireira e de minério, podem proporcionar. Mas não se pode deixar de debater os prejuízos ambientais e sociais que esses processos produtivos poderão ocasionar caso não sejam monitorados e discutidos pela populaçã local. Exemplos desses prejuízos já ocorreram em outras regiões do Amapá, notadamente na porção centro-leste onde essas atividades encontram-se consolidadas.

O cenário atual aponta para uma expropriação dos assentados no que concerne aos usos tradicionais como os SAF. Alguns assentados, por força da baixa eficiência económica dos SAF têm migrado para a atividade extrativa florestal e mineral como força de trabalho de apoio, com menor qualificação e renda. Alguns descendentes dos assentados para auxiliar na renda das famílias também executam atividades no setor de comércio e serviços na sede do município de tartarugalzinho. As mudanças sem planeamento e as incertezas no que concerne aos processos produtivos viáveis social e ambientalmente no conjunto de assentamentos são consequência tanto da falta de divisão de responsabilidades e comprometimento por parte da mineradora atuante (SPG Mineração) e madeireiros, como também pela ausência ou inoperância dos agentess governamentais, e ainda, ao que tudo indica, pela alienação e anestesiamento das lideranças locais nos assentamentos.

\section{Referências}

AMAPÁ. Macro diagnóstico do Estado do Amapá: primeira aproximação do ZEE/ Equipe Técnica do ZEE - AP. -3. ed. rev. ampl. --Macapá: IEPA, 2008.

ARCO-VERDE, Marcelo Francia e AMARO George. Cálculo de Indicadores Financeiros para Sistemas Agroflorestais. Embrapa Roraima, 2011. ISSN 1981 - 6103. 
BRASIL. Ministério dos Transportes Departamento, Nacional de Estradas de Rodagem. Diretoria de Desenvolvimento Tecnológico, Divisão de Capacitação Tecnológica. Manual de Projeto Geométrico de Rodovias Rurais. Rio de Janeiro: IPR. publ. 706, 1999.

BRASIL. Ministério dos Transportes Departamento, Nacional de Estradas de Rodagem. Diretoria de Desenvolvimento Tecnológico, Divisão de Capacitação Tecnológica. Manual de Projeto Geométrico de Rodovias Rurais. Rio de Janeiro: IPR. publ. 706, 1999.

BRASIL. Ministério do Meio Ambiente. Instrução normativa № 4, Dispõe sobre a Autorização Prévia à Análise Técnica de Plano de Manejo Florestal Sustentável- APAT, e dá outras providências. Brasília, 11 de dezembro de 2006.

BRASIL. Instituto Brasileiro de Geogrfia e Estatística. Produto Interno dos Municípios 2011. Disponível em: < http://www.ibge.gov.br/home/estatistica/economia/pibmunicipios/2011/default.shtm >. Acesso em $18 \mathrm{de}$ agosto de 2015 .

CARVALHO Márcia Siqueira de. Da economia do excedente à sujeição da renda ao capital: um breve comentário sobre a obra de José de Souza Martins. Geografia, Londrina, v. 8, n. 1, jan./jun. 1999, p. 37- 58.

CASTRO, Manoel Cabral. Desenvolvimento sustentável e gestão ambiental na formulação de políticas públicas - a experiência do estado do Amapá. Macapá: CEFORH/SEMA, 1998.

CORDANI Umberto G.; MARCOVITCH Jacques e SALATI Enéas. Avaliação das ações brasileiras após a Rio-92. Estudos Avançados 11 (29), 1997, p.309-408.

DE MATOS Bentes-Gama et.al. Análise econômica de sistemas agroflorestais na Amazônia ocidental, Machadinho d'Oeste- RO. Revista Árvore, vol. 29, núm. 3, maio-junho, 2005, pp. 401-411. ISSN: 0100-6762.

DIEESE. Estatísticas do meio rural 2010-2011. 4.ed. / Departamento Intersindical de Estatística e Estudos Socioeconômicos; Núcleo de Estudos Agrários e Desenvolvimento Rural; Ministério do Desenvolvimento Agrário. -- São Paulo: DIEESE; NEAD; MDA, 2011.

DIEESE. O Mercado de Trabalho Formal Brasileiro . Resultados da Rais 2012. Nota Técnica Número 133 - março 2014.

FRANCO, Carlos Alberto e ESTEVES, Lara Torchi. Impactos econômicos e ambientais do manejo florestal comunitário no acre: Duas experiências, resultados distintos. XLVI Congresso da Sociedade Brasileira de Economia, Administração e Sociologia Rural. Rio Branco - Acre, 20 a 23 de julho de 2008.

MACIEL Hilaires lima. Arranjos agroflorestais no contexto da agroecologia - o caso dos agricultores do assentamento agroextrativista do Maracá, Médio Rio Preto, Município do Mazagão - Amapá /DISSERTAÇÃO DE MESTRADO. Macapá, 2014.

MORAES, Luiz Fernando Duare de. Sistemas agroflorestais para uso sustentável do solo: considerações agroecológicas e socioeconômicas. Seropédica: Embrapa Agrobiologia, 2011.

MIRANDA, E. E. de; (Coord.). Brasil em Relevo. Campinas: Embrapa Monitoramento por Satélite, 2005. Disponível em: <http://www.relevobr.cnpm.embrapa.br>. Acesso em 24 de junho de 2013.

SANTOS, Milton. A natureza do espaço: técnica e tempo, razão e emoção. 3. ed. São Paulo: Hucitec, 1999.

SÃO PAULO. Manual Básico de Estradas e Rodovias Vicinais. Volume I. Planejamento, projeto, construção, operação. Departamento de Estradas de Rodagem do Estado de São Paulo. DER- São Paulo: 2012.

SOARES Jorge Luís Nascimento. A organização territorial de assentamentos rurais para atender a legislação ambiental na Amazônia. Campo-Território: revista de geografia agrária, v.3, n. 6. Agosto. 2008, p. 143-155.

SPG MINERAÇÃO S.A. Tartarugal Grande Iron Ore. Disponível em: <http://www.spgmineracao.com.br/SPG_MineracaoAN.pdf>. Acesso em 06 de setembro de 2013.

SPIER, Carlos Alberto e FERREIRA FILHO, César Fonseca. Geologia, estratigrafia e depósitos minerais do Projeto Vila Nova, escudo das guianas, Amapá, Brasil. Revista Brasileira de Geociências 29(2) junho de 1999, p. 173178. 